\title{
Feeding by red-tide dinoflagellates on the cyanobacterium Synechococcus
}

\author{
Hae Jin Jeong ${ }^{1, *}$, Jae Yeon Park ${ }^{1}$, Jae Hoon Nho ${ }^{2}$, Myung Ok Park ${ }^{1}$, Jeong Hyun Ha ${ }^{1}$, \\ Kyeong Ah Seong ${ }^{1}$, Chang Jeng ${ }^{3}$, Chi Nam Seong ${ }^{4}$, Kwang Ya Lee ${ }^{5}$, Won Ho Yih ${ }^{6}$ \\ ${ }^{1}$ School of Earth and Environmental Sciences, College of Natural Sciences, Seoul National University, Seoul 151-747, \\ Republic of Korea \\ ${ }^{2}$ Korean Oceanographic Research and Development Institution, Ansan 426-744, Republic of Korea \\ ${ }^{3}$ Institute of Marine Biology, National Taiwan Ocean University, 2 Pei-Ning Rd., Keelung 20224, Taiwan, ROC \\ ${ }^{4}$ Department of Biological Science, School of Natural Science, Sunchon National University, Sunchon 540-742, Republic of Korea \\ ${ }^{5}$ Rural Research Institute, Korea Agricultural \& Rural Infrastructure Corporation, Sa-dong, Sangrok-Gu, Ansan, \\ Gyonggi 426-170, Republic of Korea \\ ${ }^{6}$ Department of Oceanography, College of Ocean Science and Technology, Kunsan National University, Kunsan 573-701, \\ Republic of Korea
}

\begin{abstract}
We investigated the feeding by 18 red-tide dinoflagellate species on the cyanobacterium Synechococcus sp. We also calculated grazing coefficients by combining the field data on abundances of the dinoflagellates Prorocentrum donghaiense and P. micans and co-occurring Synechococcus spp. with laboratory data on ingestion rates obtained in the present study. All 17 cultured red-tide dinoflagellates tested (Akashiwo sanguinea, Alexandrium catenella, A. minutum, A. tamarense, Cochlodinium polykrikoides, Gonyaulax polygramma, G. spinifera, Gymnodinium catenatum, G. impudicum, Heterocapsa rotundata, $H$. triquetra, Karenia brevis, Lingulodinium polyedrum, Prorocentrum donghaiense, $P$. minimum, P. micans, and Scrippsiella trochoidea) were able to ingest Synechococcus. Also, Synechococcus cells were observed inside the protoplasms of $P$. triestinum cells collected from the coastal waters off Shiwha, western Korea, during red tides dominated by the dinoflagellate in July 2005. When prey concentrations were 1.1 to $2.3 \times 10^{6} \mathrm{cells} \mathrm{ml}^{-1}$, the ingestion rates of these cultured red-tide dinoflagellates on Synechococcus sp. (1.0 to 64.2 cells dinoflagellate ${ }^{-1} \mathrm{~h}^{-1}$ ) generally increased with increasing size of the dinoflagellate predators (equivalent spherical diameters $=5.2$ to $38.2 \mu \mathrm{m}$ ). The ingestion rates of $P$. donghaiense and P. micans on Synechococcus sp. increased with increasing mean prey concentration, with saturation occurring at a mean prey concentration of approximately 1.1 to $1.4 \times 10^{6} \mathrm{cells}^{-1}$. The maximum ingestion and clearance rates of P. micans on Synechococcus sp. (38.2 cells dinoflagellate $\mathrm{h}^{-1} \mathrm{and}^{-1}$ $4.3 \mu$ linoflagellate ${ }^{-1} \mathrm{~h}^{-1}$ ) were much higher than those of $P$. donghaiense on the same prey species ( 7.7 cells dinoflagellate ${ }^{-1} \mathrm{~h}^{-1}$ and $2.6 \mu$ l dinoflagellate $\mathrm{e}^{-1} \mathrm{~h}^{-1}$ ). The ingestion rates of red-tide dinoflagellates on Synechococcus sp. were comparable to those of the heterotrophic nanoflagellates and ciliates on Synechococcus spp., so far reported in the literature. The calculated grazing coefficients attributable to small Prorocentrum spp. (P. donghaiense + P. minimum) and P. micans on co-occurring Synechococcus spp. were up to 3.6 and $0.15 \mathrm{~h}^{-1}$, respectively. The results of the present study suggest that red-tide dinoflagellates potentially have a considerable grazing impact on populations of Synechococcus.
\end{abstract}

KEY WORDS: Cyanophyte · Grazing · Harmful algal bloom · Ingestion · Marine $\cdot$ Protist $\cdot$ Red tide Resale or republication not permitted without written consent of the publisher

\section{INTRODUCTION}

The photosynthetic cyanobacterium Synechococcus is a ubiquitous prokaryote in marine environments, present from tropical waters to polar waters (Walker \&
Marchant 1989, Burkill et al. 1993, Chavez et al. 1996, Landry et al. 1996, Vezina \& Vincent 1997, Campbell et al. 1998, Zubkov et al. 1998, Sherry \& Wood 2001, Liu et al. 2002, Mackey et al. 2002, DiTullio et al. 2003, Maranon et al. 2003). It often dominates the abun- 
dance and/or the primary production of phytoplankton in both coastal and open oceanic waters (Chang et al. 1996, 2003, Karlson et al. 1996, Phlips \& Badylak 1996, Agawin et al. 1998, Yahel et al. 1998, Crosbie \& Furnas 2001, Arin et al. 2002, Chiang et al. 2002, Stal et al. 2003, Nielsen et al. 2004, Wawrik \& Paul 2004). The abundance of Synechococcus spp. often exceeds $10^{5}$ cells $\mathrm{ml}^{-1}$ and sometimes forms red tides (Lindell \& Post 1995, Partensky et al. 1996, 1999, Morel 1997, Andreoli et al. 1999, Diaz \& Maske 2000, Uysal 2000, Agawin et al. 2003, Murrell \& Lores 2004). In oceanic waters, Synechococcus has been thought to be one of the major contributors to $\mathrm{CO}_{2}$ and nutrient uptake from ambient waters and, in turn, eventually from the atmosphere (Maranon et al. 2003). Therefore, the growth and mortality of Synechococcus are important factors in understanding the cycling of the materials in marine planktonic food webs.

There have been many studies on the growth of Synechococcus, in particular the effects of iron concentrations on its growth (Wells et al. 1994, Henley \& Yin 1998, Timmermans et al. 1998, Yin \& Henley 1999). Also, there have been a large number of studies on the mortality of Synechococcus due to predation by heterotrophic protists (Campbell \& Carpenter 1986, Kuosa 1990, Caron et al. 1991, Strom 1991, Šimek 1997, Dolan \& Šimek 1998, 1999, Lewitus et al. 1998, Ochs \& Eddy 1998, Christaki et al. 1999, Monger et al. 1999, Rivkin et al. 1999, Cowlishaw 2000, Boenigk et al. 2001, Guillou et al. 2001, Pitta et al. 2001, Quevedo \& Anadon 2001, Bettarel et al. 2002, Jochem 2003, Agawin et al. 2004). Many studies on the feeding by heterotrophic protists on Synechococcus have suggested that heterotrophic nanoflagellates and ciliates are usually major grazers on Synechococcus (Bettarel et al. 2002, Jochem 2003, Worden \& Binder 2003, Agawin et al. 2004). Here, an important question concerning the protistan predators on Synechococcus arises: Is there any unknown predator which can affect the population dynamics of Synechococcus?

Dinoflagellates are ubiquitous protists and sometimes form red-tide patches in coastal (e.g. Jeong 1995) and offshore and/or oceanic waters (e.g. Tyler \& Seliger 1978, Tester \& Steidinger 1997). Red tides dominated by dinoflagellates can alter the balance of food webs and cause large-scale mortalities of fish and shellfish. Recently, many red-tide dinoflagellates, which had previously been thought to be exclusively autotrophic dinoflagellates, have been revealed to be mixotrophic dinoflagellates (Bockstahler \& Coats 1993, Chang \& Carpenter 1994, Jacobson \& Anderson 1996, Granéli et al. 1997, Stoecker et al. 1997, Stoecker 1999, Skovgaard et al. 2000, Smalley et al. 2003, Jeong et al. $2004,2005 a, b)$. These dinoflagellates usually co-occur with Synechococcus and/or the blooms of these dinoflagellates sometimes succeed those of Synechococcus (Taslakian \& Hardy 1976, Chavez et al. 1996, Tarran et al. 1999, 2001, Duyl et al. 2002, Murrell \& Lores 2004). There is a possibility that red-tide dinoflagellates feed on Synechococcus; however, the interactions between red-tide dinoflagellates and Synechococcus, in particular possible predator-prey relationships, are still poorly understood.

There have been few studies on the feeding by redtide dinoflagellates on Synechococcus (Legrand et al. 1998). Legrand et al. (1998) reported that Synechococcus was not ingested by the red-tide dinoflagellate Heterocapsa triquetra. However, we have recently found that some red-tide dinoflagellates, including $H$. triquetra, are able to ingest Synechococcus. Therefore, the following basic questions arise: (1) Are most red-tide dinoflagellates able to ingest Synechococcus? (2) What is the range of ingestion rates of red-tide dinoflagellates on Synechococcus? Are the ingestion rates of red-tide dinoflagellates on Synechococcus comparable to those of heterotrophic nanoflagellates and ciliates? (3) What is the potential grazing impact by red-tide dinoflagellates on Synechococcus? If most red-tide dinoflagellates are able to ingest Synechococcus, we must change conventional views about the planktonic food webs related to Synechococcus and to dinoflagellates, and the mechanisms of outbreak and persistence of red tides, etc.

We (1) investigated whether or not 17 cultured redtide dinoflagellates, having a wide range of morphological properties (size, shape, single or chain forms, thecate or naked, etc.), were able to feed on Synechococcus; (2) observed Prorocentrum triestinum cells collected from the coastal waters off Shiwha, western Korea, during the red tide dominated by the dinoflagellate in July 2005, to ascertain the feeding by dinoflagellates on Synechococcus in natural environments; (3) conducted experiments to determine the ingestion rates of those 17 cultured red-tide dinoflagellates on Synechococcus at a single high-prey concentration, and (4) measured the ingestion rates of Prorocentrum donghaiense (previously P. dentatum in Korean, Chinese, Japanese, and in some United States waters) and P. micans on Synechococcus as a function of the prey concentration. (5) The ingestion rates of red-tide dinoflagellates on Synechococcus were compared to those of heterotrophic nanoflagellates and ciliates reported in the literature. (6) We also estimated the grazing coefficients attributable to small Prorocentrum spp. (P. donghaiense and P. minimum) and $P$. micans on co-occurring Synechococcus using our data for ingestion rates obtained from laboratory experiments and the abundances of predator and prey in the field. The results of the present study provide a basis for understanding the interactions between red-tide dinoflagellates and co-occurring Synechococcus and their population dynamics. 


\section{MATERIALS AND METHODS}

Preparation of experimental organisms. Synechococcus sp. (SYN, Genbank Accession Number DQ023295, equivalent spherical diameter $[\mathrm{ESD}]=$ ca. $1 \mu \mathrm{m}$ ) was grown at $20^{\circ} \mathrm{C}$ in enriched $f / 2$ seawater media (Guillard \& Ryther 1962) without silicate, under a $14: 10 \mathrm{~h}$ light:dark cycle of $20 \mu \mathrm{E} \mathrm{m}^{-2} \mathrm{~s}^{-1}$ of cool white fluorescent light, while dinoflagellate predators were grown under a 14:10 h light:dark cycle of $30 \mu \mathrm{E} \mathrm{m}^{-2} \mathrm{~s}^{-1}$ (Table 1). Mean ESDs $( \pm \mathrm{SD}$ ) of the dinoflagellates were measured by an electronic particle counter (Coulter Multisizer II, Coulter Corporation). Cultures in their exponential growth phase were used for these feeding experiments.

Feeding occurrence. Expt 1 was designed to investigate whether or not each dinoflagellate species was able to feed on Synechococcus (Table 1).

A dense culture of each dinoflagellate predator, maintained in $f / 2$ media and growing photosynthetically in its exponential growth phase on shelves and incubated under a 14:10 h light:dark cycle of $30 \mu \mathrm{E} \mathrm{m}{ }^{-2}$ $\mathrm{s}^{-1}$, was transferred to a $1 \mathrm{l}$ polycarbonate $(\mathrm{PC})$ bottle containing freshly filtered seawater. Three $1 \mathrm{ml}$ aliquots were then removed from the bottle and examined using a compound microscope to determine the dinoflagellate concentration.

In this experiment, the initial concentrations of each dinoflagellate predator (2000 to 20000 cells ml$^{-1}$ ) and Synechococcus ( 1 to $2 \times 10^{6}$ cells ml ${ }^{-1}$ ) were established using an autopipette to deliver a predetermined volume of culture with a known cell density to the

Table 1. Cultured dinoflagellate species used as predators on Synechococcus in Expts 1 and 2. Mean equivalent spherical diameter $(E S D, \mu m)( \pm S D)$ was measured by an electronic particle counter measured before these experiments; $n>2000$ for each species

\begin{tabular}{|lr|}
\hline Predator species & ESD $( \pm \mathrm{SD})$ \\
\hline Heterocapsa rotundata & $5.8(0.4)$ \\
Prorocentrum minimum & $12.1(2.5)$ \\
Prorocentrum donghaiense & $13.3(2.0)$ \\
Heterocapsa triquetra & $15.0(4.3)$ \\
Alexandrium minutum & $16.7(2.9)$ \\
Gymnodinium impudicum & $17.8(2.6)$ \\
Karenia brevis & $20.3(1.1)$ \\
Scrippsiella trochoidea & $22.8(2.7)$ \\
Cochlodinium polykrikoides & $25.9(2.9)$ \\
Prorocentrum micans & $26.6(2.8)$ \\
Alexandrium tamarense & $28.1(3.1)$ \\
Akashiwo sanguinea & $30.8(3.5)$ \\
Gonyaulax polygramma & $32.5(3.0)$ \\
Alexandrium catenella & $32.6(2.7)$ \\
Gymnodinium catenatum & $33.9(1.6)$ \\
Gonyaulax spinifera & $35.0(1.3)$ \\
Lingulodinium polyedrum & $38.2(3.6)$ \\
\hline
\end{tabular}

experimental bottles. Triplicate $80 \mathrm{ml} \mathrm{PC}$ bottles (mixtures of dinoflagellate predator and Synechococcus) and triplicate predator control bottles (containing dinoflagellate predator only) were set up at a single prey concentration for each dinoflagellate predator. The bottles were filled to capacity with freshly filtered seawater, capped, and then placed on a shelf at $20^{\circ} \mathrm{C}$ under the continuous illumination of $30 \mu \mathrm{E} \mathrm{m} \mathrm{m}^{-2} \mathrm{~s}^{-1}$. After 5, 10, 30, and $60 \mathrm{~min}$, and $4 \mathrm{~h}$ of incubation, a $10 \mathrm{ml}$ aliquot was removed from each bottle and then fixed with formalin (final conc. $=4 \%$ ). The fixed aliquots were filtered onto $3 \mu \mathrm{m}$ pore size, $25 \mathrm{~mm}$ PC black membrane filters, and then the concentrated cells on the membranes were observed under an epifluorescent microscope (Olympus BH2, Olympus) with blue light excitation at a magnification of $1000 \times$ to determine whether or not each dinoflagellate predator was able to feed on Synechococcus. However, ingested Synechococcus cells were rarely detectable in the protoplasms of Akashiwo sanguinea, Lingulodinium polyedrum, and Scrippsiella trochoidea under the epifluorescent microscope. Therefore, after conducting the same processes as described above, except for the Synechococcus cells being fluorescently labeled using DTAF (Siegler et al. 1989), the concentrated cells on the membranes were observed under a confocal laser scanning microscope (CLSM: Carl Zeiss-LSM510) at a magnification of $1000 \times$ by scanning the dinoflagellate body at consecutive intervals of 1 to $2 \mu \mathrm{m}$ along the $z$ axis. Pictures showing ingested Synechococcus cells inside each dinoflagellate predator cell were taken using digital cameras on these microscopes at a magnification of $1000 \times$.

To observe ingested Synechococcus cells inside the protoplasms of dinoflagellate predator cells collected from natural environments, we took water samples using a clean bucket from the surface of the coastal waters off Siwha, Ansan, western Korea, during red tides dominated by Prorocentrum triestinum in July 2005. The water samples were poured into $100 \mathrm{ml}$ polyethylene bottles and immediately preserved with formalin (final conc. $=4 \%$ ). The fixed aliquots were filtered onto $5 \mu \mathrm{m}$ pore size, $25 \mathrm{~mm}$ PC black membrane filters, and then the concentrated cells on the membranes were observed under the epifluorescent microscope with blue light excitation at a magnification of $1000 \times$.

Ingestion rates. Expt 2 was designed to compare the ingestion rates of cultured red-tide dinoflagellates on Synechococcus when similar prey concentrations were provided. We provided live Synechococcus at initial concentrations of 1.1 to $2.3 \times 10^{6} \mathrm{cells} \mathrm{m}^{-1}$ for the dinoflagellate predators, because the ingestion rates of Prorocentrum donghaiense and P. micans on Synechococcus were almost saturated at these prey concentrations (see 
Figs. 2 \& 3). Two different methods were used for these experiments; the first method involved measuring ingestion rates by plotting the numbers of ingested Synechococcus cells (seen as orange-colored inclusions under an epifluorescence microscope) inside the protoplasm of a dinoflagellate against incubation time, as in Sherr et al. (1987). This method was used for Heterocapsa triquetra, Karenia brevis, P. donghaiense, and P. micans inside which all the ingested prey cells were easily seen and each ingested prey cell was clearly countable. The second method was measuring ingestion rates by comparing concentrations of the dinoflagellate predator and Synechococcus between the experimental and control bottles. This method was used for the other dinoflagellate predators inside which all ingested prey cells could not be seen and/or each ingested prey cell was not clearly countable. To assess how close the results from these 2 methods are, ingestion rates of $P$. donghaiense on Synechococcus were measured using both of these methods.

A dense culture of each dinoflagellate predator maintained in an f/2 medium and growing photosynthetically in its exponential phase under a 14:10 h light:dark cycle of $30 \mu \mathrm{E} \mathrm{m} \mathrm{m}^{-2} \mathrm{~s}^{-1}$ for ca. 1 mo was transferred into a $11 \mathrm{PC}$ bottle. Three $1 \mathrm{ml}$ aliquots from the bottle were counted using a compound microscope, to determine cell concentrations of the dinoflagellate predator, and the cultures were then used to conduct experiments.

For the first method (prey-inclusion method), initial concentrations of the dinoflagellate predator (2000 to 20000 cells ml-1) and live Synechococcus were established using an autopipette to deliver predetermined volumes of known cell concentrations to the bottles. Triplicate $80 \mathrm{ml}$ PC experimental bottles (containing mixtures of predators and prey) and triplicate predator-control bottles (containing predators only) were also established. Then, $20 \mathrm{ml}$ of $\mathrm{f} / 2$ medium was added to all the bottles, which were then filled to capacity with freshly filtered seawater, capped, and then placed on the shelf. After 1, 5, 10, and 20 min of incubation, $10 \mathrm{ml}$ aliquots were removed from each bottle, transferred into $20 \mathrm{ml}$ vials, and then fixed with formalin (final conc. $=4 \%$ ). One $2 \mathrm{ml}$ fixed aliquot was filtered onto $3 \mu \mathrm{m}$ pore size, PC black membrane filters. Orange-colored inclusions (Synechococcus cells) inside the protoplasm of $>30$ dinoflagellate predator cells on the PC black membrane filters were enumerated under an epifluorescence microscope with blue light excitation. No orange-colored inclusions were observed inside the protoplasm of the dinoflagellate predators in the control bottles. Prorocentrum spp. cells in old cultures ( $>1$ mo after being transferred) sometimes contained yellow-colored inclusions, even when prey cells were not provided. Therefore, we used only Prorocentrum spp. in cultures of $<7 \mathrm{~d}$ after being transferred to new medium and ascertained that there were no yellow-colored inclusions seen under an epifluorescence microscope. The bottles were capped, placed on a shelf, and incubated as described above. A linear regression curve for the number of prey cells inside a dinoflagellate predator cell against incubation time was obtained, and then an ingestion rate (prey cells dinoflagellate ${ }^{-1} \mathrm{~h}^{-1}$ ) was calculated by exploration, as in Sherr et al. (1987).

For the second method (bottle-incubation method), the initial concentrations of the dinoflagellate predators and live Synechococcus were established using an autopipette, to deliver predetermined volumes of known cell concentrations to the bottles. Triplicate $80 \mathrm{ml}$ PC experimental bottles (containing mixtures of predators and prey), triplicate prey-control bottles (containing prey only), and triplicate predator-control bottles (containing predators only) were also established. Then, $20 \mathrm{ml}$ of $\mathrm{f} / 2$ medium was added to all the bottles, which were then filled to capacity with freshly filtered seawater, capped, placed on the shelf, and incubated at $20^{\circ} \mathrm{C}$ under an illumination of $30 \mu \mathrm{E} \mathrm{m} \mathrm{m}^{-2}$ $\mathrm{s}^{-1}$. To determine the actual initial predator and prey densities (cells $\mathrm{ml}^{-1}$ ) at the beginning of the experiment and after $6 \mathrm{~h}$ incubation, a $5 \mathrm{ml}$ aliquot was removed from each bottle and fixed with $5 \%$ Lugol's solution. All or $>300$ dinoflagellate predator cells, fixed in Lugol's solution, in three $1 \mathrm{ml}$ Sedgwick-Rafter counting chambers were enumerated. Another $5 \mathrm{ml}$ aliquot was removed from each bottle, fixed with formalin (final conc. $=4 \%$ ), and then filtered onto $0.2 \mu \mathrm{m}$ pore size, PC black membrane filters. Orange-colored prey cells on the PC filter were enumerated under an epifluorescence microscope. Ingestion and clearance rates were calculated using the equations of Frost (1972) and Heinbokel (1978).

Effects of prey concentration. Expt 3 was designed to investigate the ingestion rates of Prorocentrum donghaiense and P. micans on Synechococcus as a function of prey concentration. The actual initial predator (and prey) concentrations were 13 to 16570 cells $\mathrm{ml}^{-1}$ (111 to 2996200 ; 9 prey concentrations) for $P$. donghaiense and 10 to 3260 cells ml ${ }^{-1}$ (131 to 3438500 ; 9 prey concentrations) for $P$. micans. Using the first method (prey-inclusion method), as in Expt 2, triplicate ingestion rates at each prey concentration were obtained. All ingestion rate data were fitted to a Michaelis-Menten equation:

$$
I R=\frac{I_{\max }(x)}{K_{I R}+(x)}
$$

where $I_{\max }$ is the maximum ingestion rate (cells dinoflagellate $\mathrm{h}^{-1}$ ), $\mathrm{x}$ is the prey concentration (cells $\mathrm{ml}^{-1}$ ), and $K_{I R}$ is the prey concentration sustaining one-half $I_{\max }$. 
Potential grazing impact. We estimated the grazing coefficients (mortality rate due to predation) attributable to small Prorocentrum spp. ( $P$. donghaiense $+P$. minimum) and $P$. micans on Synechococcus by combining field data on abundances of the dinoflagellate predators and Synechococcus with ingestion rates of the dinoflagellate predators on Synechococcus obtained in the present study. The ingestion rate of $P$. minimum on Synechococcus at a certain prey concentration was calculated by multiplying that of $P$. donghaiense by 0.81 , because the ingestion rate of $P$. minimum on Synechococcus at a prey concentration of $1.83 \times 10^{6} \mathrm{cells} \mathrm{ml}^{-1}$ (5.9 cells dinoflagellate $^{-1} \mathrm{~h}^{-1}$ ) was 0.81 times lower than that of $P$. donghaiense at the same prey concentration ( 7.3 cells dinoflagellate ${ }^{-1}$ $\mathrm{h}^{-1}$ ), calculated using the equation of the regression curve in Fig. 2. Data on the abundances of small Prorocentrum spp. (P. donghaiense $+P$. minimum), P. micans, and the co-occurring Synechococcus used in this estimation were obtained from the water samples off Masan (bay waters, in 2004) and at 6 stations 90 to $220 \mathrm{~km}$ off Jeju Island (offshore and oceanic waters, in 2003), Korea.

The grazing coefficients $\left(g, \mathrm{~h}^{-1}\right)$ were calculated as:

$$
g=C R \times G C
$$

where $C R\left(\mathrm{ml}\right.$ dinoflagellate $\left.\mathrm{e}^{-1} \mathrm{~h}^{-1}\right)$ is a clearance rate of an algal predator on a target prey at a prey concentration and $G C$ is a grazer concentration (cells $\mathrm{ml}^{-1}$ ). $C R$ values were calculated as:

$$
C R=I R / P C
$$

where $I R$ (cells eaten dinoflagellate ${ }^{-1}$ $\mathrm{h}^{-1}$ ) is the ingestion rate of the algal predator on the target prey and $P C$ (cells $\mathrm{ml}^{-1}$ ) is a prey concentration. $C R \mathrm{~s}$ were corrected using $Q_{10}=2.8$ (Hansen et al. 1997), because in situ water temperatures and the temperature used in the laboratory for this experiment $\left(20^{\circ} \mathrm{C}\right)$ were sometimes different.

\section{RESULTS}

\section{Dinoflagellate predators}

All cultured red-tide dinoflagellates tested (Akashiwo sanguinea, Alexandrium catenella, A. minutum, A. tamarense, Cochlodinium polykrikoides, Gonyaulax polygramma, G. spinifera, Gymnodinium catenatum, G. impudicum, Heterocapsa rotundata, $H$. triquetra, Karenia brevis, Lingulodinium polyedrum, Prorocentrum donghaiense, $P$. minimum, $P$. micans, and
Scrippsiella trochoidea) were able to ingest both live and fluorescent-labeled Synechococcus (Fig. 1A-Q). Ingested Synechococcus cells were usually found aggregated in 1 or 2 areas of the protoplasm of the thecate dinoflagellates $H$. triquetra, $L$. polyedrum, and $S$. trochoidea, while they were widely distributed in the protoplasm of $P$. donghaiense and P. micans and the naked dinoflagellates C. polykrikoides and G. catenatum (Fig. 1).

Synechococcus cells were observed inside the protoplasm of dinoflagellate (Prorocentrum triestinum) cells collected from the surface of coastal waters off Shiwha, western Korea, during red tides dominated by the dinoflagellate in July 2005 (Fig. 1R).

\section{Ingestion rates of diverse dinoflagellate predators}

The ingestion rate of Prorocentrum donghaiense on Synechococcus, measured using the second method (bottle-incubation method) at an initial prey concentration of $2.3 \times 10^{6}$ cells ml $^{-1}$ ( 8.2 cells dinoflagellate ${ }^{-1} \mathrm{~h}^{-1}$ ), was only $10 \%$ higher than the ingestion rate at the same prey concentration calculated using the equation of the regression line on the ingestion rates measured using the first method (prey-inclusion method) (7.4 cells dinoflagellate ${ }^{-1} \mathrm{~h}^{-1}$ ) (Table 2, Fig. 2).

When the initial prey concentrations of Synechococcus were 1.1 to $2.3 \times 10^{6}$ cells $\mathrm{ml}^{-1}$, the ingestion rates of the red-tide dinoflagellates on Synechococcus

Table 2. Ingestion rates (means, SEs in parentheses) of the dinoflagellate predators on Synechococcus, measured using 2 different methods in Expt 2 (see 'Materials and methods'). BI: bottle-incubation method; PI: prey-inclusion method

\begin{tabular}{|lccc|}
\hline Predator species & Method & $\begin{array}{c}\text { Initial concentrations } \\
\text { of Synechococcus } \\
\left(10^{6} \mathrm{cells} \mathrm{ml}^{-1}\right)\end{array}$ & $\begin{array}{c}\text { Ingestion rate } \\
\left(\text { cells dinoflagel- }^{-1} \text { late }^{-1} \mathrm{ml}^{-1}\right)\end{array}$ \\
\hline Heterocapsa rotundata & BI & $1.17(0.04)$ & $1.0(0.2)$ \\
Prorocentrum minimum & BI & $1.83(0.04)$ & $5.9(1.2)$ \\
Prorocentrum donghaiense & BI & $2.25(0.10)$ & $8.2(0.4)$ \\
Prorocentrum donghaiense & PI & 2.25 & $7.4^{\mathrm{a}}$ \\
Heterocapsa triquetra & PI & $1.20(0.03)$ & $4.4(0.3)$ \\
Alexandrium minutum & PI & $1.09(0.01)$ & $3.2(2.2)$ \\
Gymnodinium impudicum & BI & $1.28(0.02)$ & $14.5(1.5)$ \\
Karenia brevis & BI & $1.25(0.04)$ & $5.0(0.1)$ \\
Scrippsiella trochoidea & BI & $1.26(0.04)$ & $7.1(1.1)$ \\
Cochlodinium polykrikoides & BI & $1.08(0.20)$ & $38.7(1.1)$ \\
Prorocentrum micans & PI & $1.38(0.04)$ & $35.4(2.1)$ \\
Alexandrium catenella & BI & $1.89(0.05)$ & $29.5(6.7)$ \\
Alexandrium tamarense & BI & $1.13(0.05)$ & $13.7(0.9)$ \\
Akashiwo sanguinea & BI & $1.90(0.11)$ & $62.9(5.4)$ \\
Gonyaulax polygramma & BI & $1.65(0.65)$ & $42.4(2.8)$ \\
Gymnodinium catenatum & BI & $1.00(0.04)$ & $30.2(2.8)$ \\
Gonyaulax spinifera & BI & $1.14(0.09)$ & $24.3(3.5)$ \\
Lingulodinium polyedrum & BI & $1.53(0.04)$ & $64.2(2.2)$ \\
a7.4 was calculated using the equation of the regression line in Fig. 2 \\
\hline
\end{tabular}




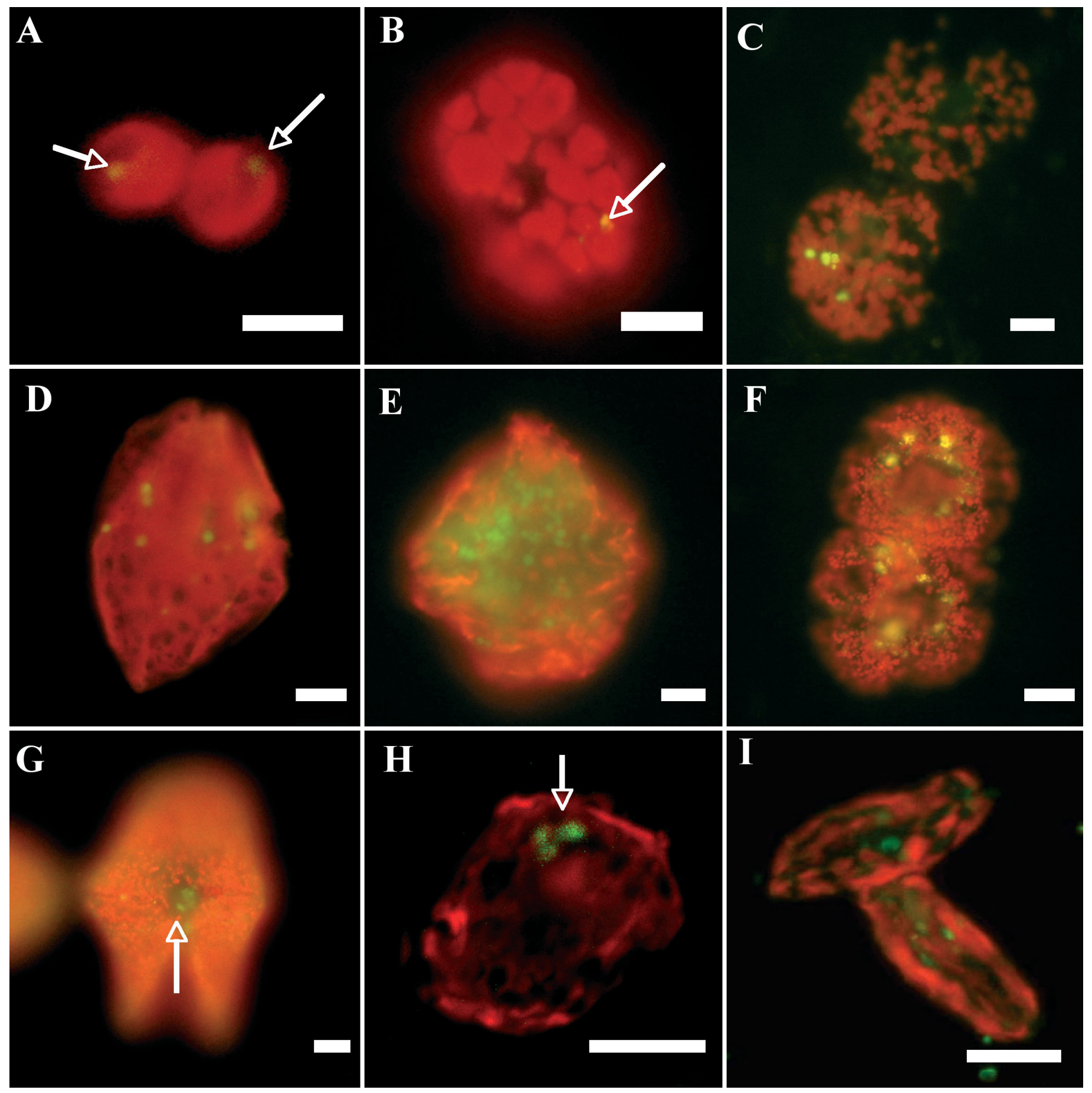

Fig. 1. Feeding by dinoflagellate predators on Synechococcus. Cultured cells of the predators and prey: (A) Heterocapsa rotundata, (B) Gymnodinium impudicum, (C) Cochlodinium polykrikoides, (D) Prorocentrum micans, (E) Gonyaulax polygramma, (F) Gymnodinium catenatum, (G) Akashiwo sanguinea, (H) P. minimum, (I) P. donghaiense, (J) H. triquetra, (K) Alexandrium minutum, (L) Karenia brevis, (M) Scrippsiella trochoidea, (N) A. catenella, (O) A. tamarense, (P) Gonyaulax spinifera, (Q) Lingulodinium polyedrum. (R) Ingested Synechococcus cells inside the protoplasm of $P$. triestinum collected from a natural water sample. Scale bars $=5 \mu \mathrm{m}$. Arrows indicate ingested prey cells. (A to G) and (R) are photomicrographs showing dinoflagellate predators ingesting live Synechococcus cells (seen as orange-colored inclusions), taken using an epifluorescence microscope, and ( $\mathrm{H}$ to $\mathrm{Q}$ ) are photomicrographs showing dinoflagellate predators ingesting fluorescently labeled Synechococcus cells (seen as green-colored inclusions), taken using a confocal laser scanning microscope 


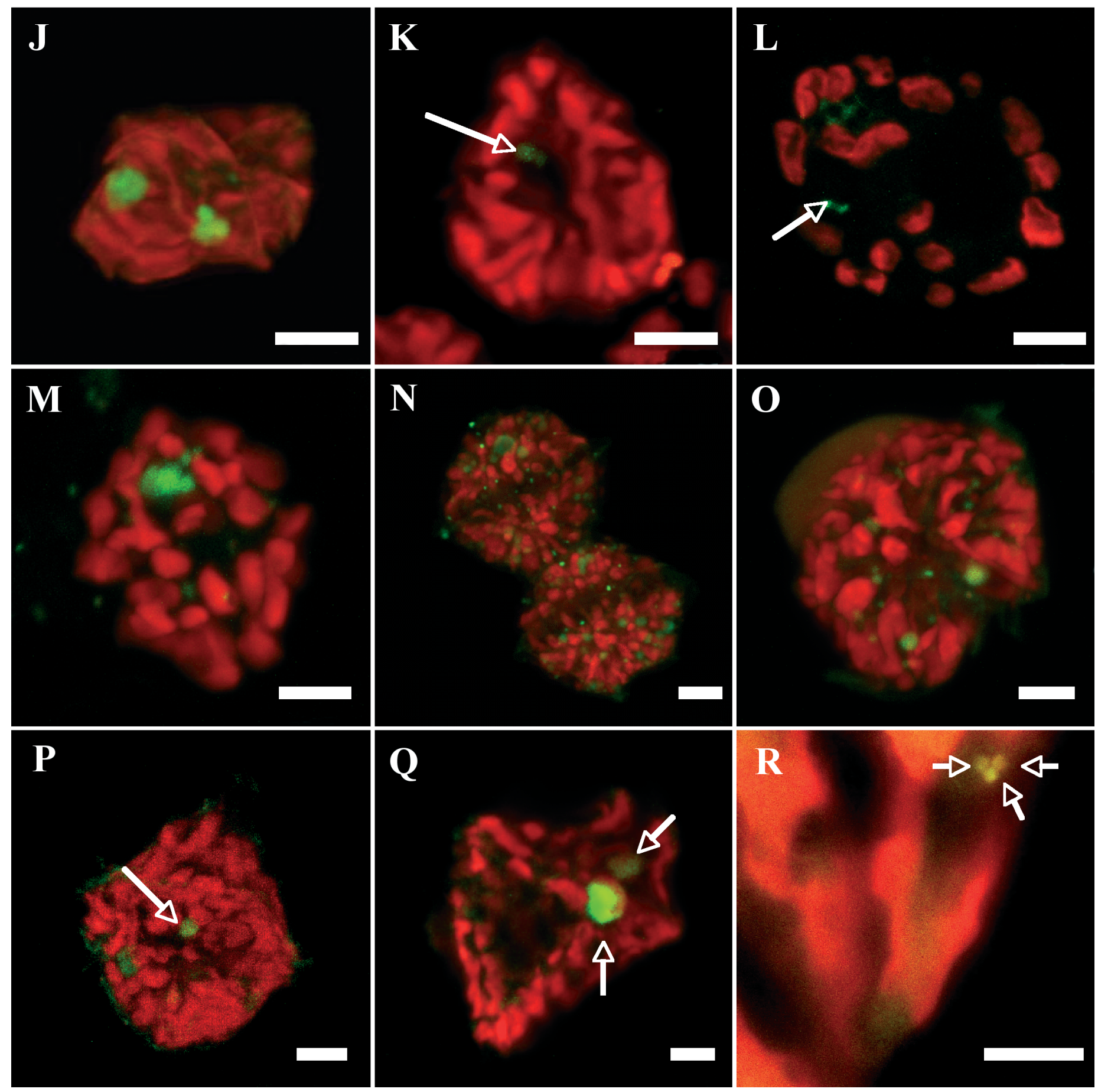

Fig. 1 (continued)

generally increased as the size of the algal predators increased (Table 2). The smallest ingestion rate (1.0 cells dinoflagellate ${ }^{-1} \mathrm{~h}^{-1}$ ) was obtained for the smallest predator Heterocapsa rodundata $(\mathrm{ESD}=$ $5.2 \mu \mathrm{m})$, while the greatest ingestion rate $(64.2$ cells dinoflagellate $\mathrm{h}^{-1}$ ) was obtained for the largest predator Lingulodinium polyedrum $(\mathrm{ESD}=38.2 \mu \mathrm{m})$.

\section{Effects of prey concentration}

The initial concentrations of Synechococcus in the experiment on the feeding by Prorocentrum donghaiense on Synechococcus were $1.1 \times 10^{2}$ to $3.0 \times 10^{6}$ cells ml ${ }^{-1}$. When being measured using the first method (prey-inclusion method), with increasing Synechococcus concentration, 


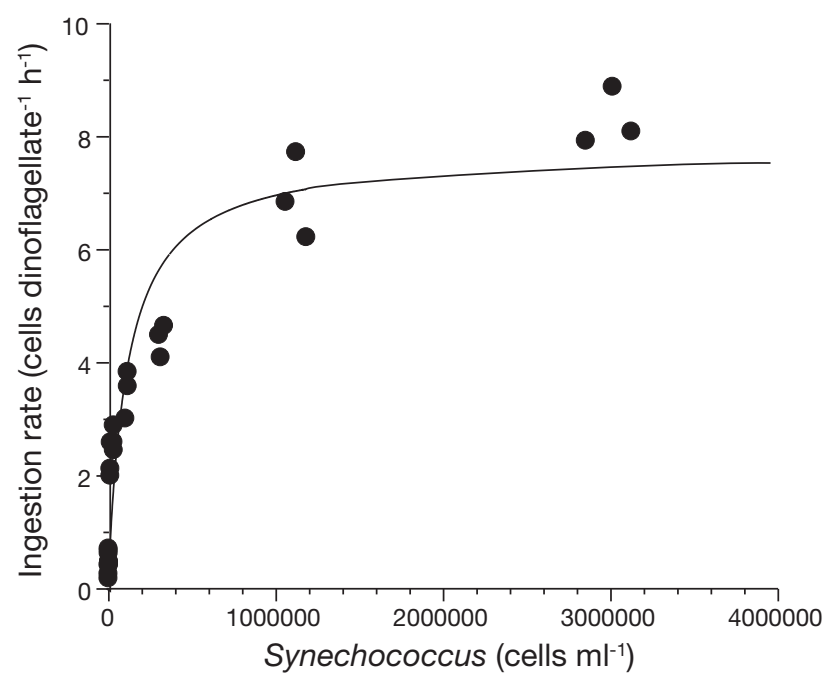

Fig. 2. Ingestion rate (cells dinoflagellate $\mathrm{e}^{-1} \mathrm{~h}^{-1}$ ) of Prorocentrum donghaiense on Synechococcus as a function of the initial prey concentration (cells ml-1). Each value of the ingestion rates was calculated by exploration from a linear regression curve on the number of prey cells inside a dinoflagellate predator cell over incubation time (see 'Materials and methods' for calculation). Symbols represent single treatments. The curves were fitted by a Michaelis-Menten equation (Eq. 1) using all treatments in the experiment. Ingestion rate $\left(I R\right.$, cells dinoflagellate $\left.{ }^{-1} \mathrm{~h}^{-1}\right)=7.7[\mathrm{x} /(114000+\mathrm{x})], \mathrm{r}^{2}=0.909$, where $x$ is the prey concentration

the ingestion rate of $P$. donghaiense on Synechococcus increased, with saturation at a prey concentration of approximately $1.1 \times 10^{6}$ cells ml $^{-1}$ (Fig. 2). When the data were fitted to Eq. (1), the maximum ingestion rate of $P$. donghaiense on Synechococcus was 7.7 cells dinoflagellate $\mathrm{h}^{-1}$. The maximum clearance rate of $P$. donghaiense on Synechococcus was $2.6 \mu \mathrm{l}$ dinoflagellate $\mathrm{h}^{-1}$.

The initial concentrations of Synechococcus in the experiment on the feeding by Prorocentrum micans on Synechococcus were $1.3 \times 10^{2}$ to $3.4 \times 10^{6} \mathrm{cells} \mathrm{ml}^{-1}$. With increasing prey concentration the ingestion rate of P. micans on Synechococcus increased, with saturation at a prey concentration of approximately $1.4 \times$ $10^{6}$ cells $\mathrm{ml}^{-1}$ (Fig. 3). When the data were fitted to Eq. (1), the maximum ingestion rate of $P$. micans on Synechococcus was 38.2 cells dinoflagellate ${ }^{-1} \mathrm{~h}^{-1}$. The maximum clearance rate of $P$. micans on Synechococcus was $4.3 \mu$ l dinoflagellate ${ }^{-1} \mathrm{~h}^{-1}$.

\section{Grazing impact}

The grazing coefficients attributable to Prorocentrum donghaiense on co-occurring Synechococcus in Masan Bay, Korea, were 0.1 to $3.6 \mathrm{~h}^{-1}$ (i.e. 11 to $98 \%$ of a Synechococcus population was removed by a population of $P$. donghaiense in $1 \mathrm{~h}$ ) when the abundances of $P$. donghaiense and Synechococcus were 1710 to 55000 cells ml ${ }^{-1}$ and 550 to 16130 cells ml$^{-1}$, respectively (Fig. 4A). The grazing coefficients attributable to $P$. donghaiense on co-occurring Synechococcus in the offshore and/or oceanic waters away from Jeju island, Korea, were 0.001 to $0.014 \mathrm{~h}^{-1}$ (i.e. 0.1 to $1.5 \%$ of a Synechococcus population was removed by a population of $P$. donghaiense in $1 \mathrm{~h}$ ) when the abundances of $P$. donghaiense and Synechococcus were 12 to 328 cells ml ${ }^{-1}$ and 70110 to 203140 cells ml ${ }^{-1}$, respectively (Fig. 4A).

The grazing coefficients attributable to Prorocentrum micans on co-occurring Synechococcus in Masan Bay were 0.04 to $0.15 \mathrm{~h}^{-1}$ (i.e. up to 4 to $17 \%$ of a Synechococcus population was removed by a population of $P$. micans in $1 \mathrm{~h}$ ) when the abundances of $P$. micans and Synechococcus were 100 to 461 cells ml ${ }^{-1}$ and 547 to 9840 cells ml $^{-1}$, respectively (Fig. 4B).

\section{DISCUSSION}

\section{Dinoflagellate predators on Synechococcus}

All red-tide dinoflagellates tested in the present study were able to ingest Synechococcus. Dinoflagellates not tested yet are also likely able to feed on Synechococcus. We reported here for the first time that Alexandrium catenella, A. minutum, Heterocapsa rotundata (previously Katodinium rotundatum), and

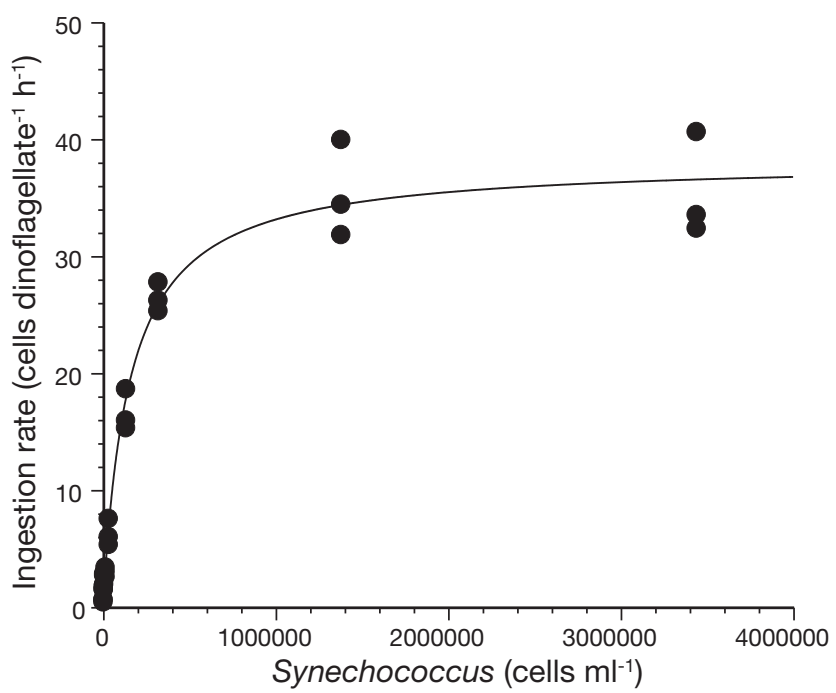

Fig. 3. Ingestion rate (cells dinoflagellate ${ }^{-1} \mathrm{~h}^{-1}$ ) of Prorocentrum micans on Synechococcus as a function of the initial prey concentration (cells $\mathrm{ml}^{-1}$ ). Each value of the ingestion rates was calculated as for Fig. 2. Symbols represent single treatments. The curves were fitted by a Michaelis-Menten equation (Eq. 1) using all treatments in the experiment. Ingestion rate $\left(I R\right.$, cells dinoflagellate $\left.{ }^{-1} \mathrm{~h}^{-1}\right)=38.2[x /(152000+x)], \mathrm{r}^{2}=0.980$ ， where $x$ is the prey concentration 

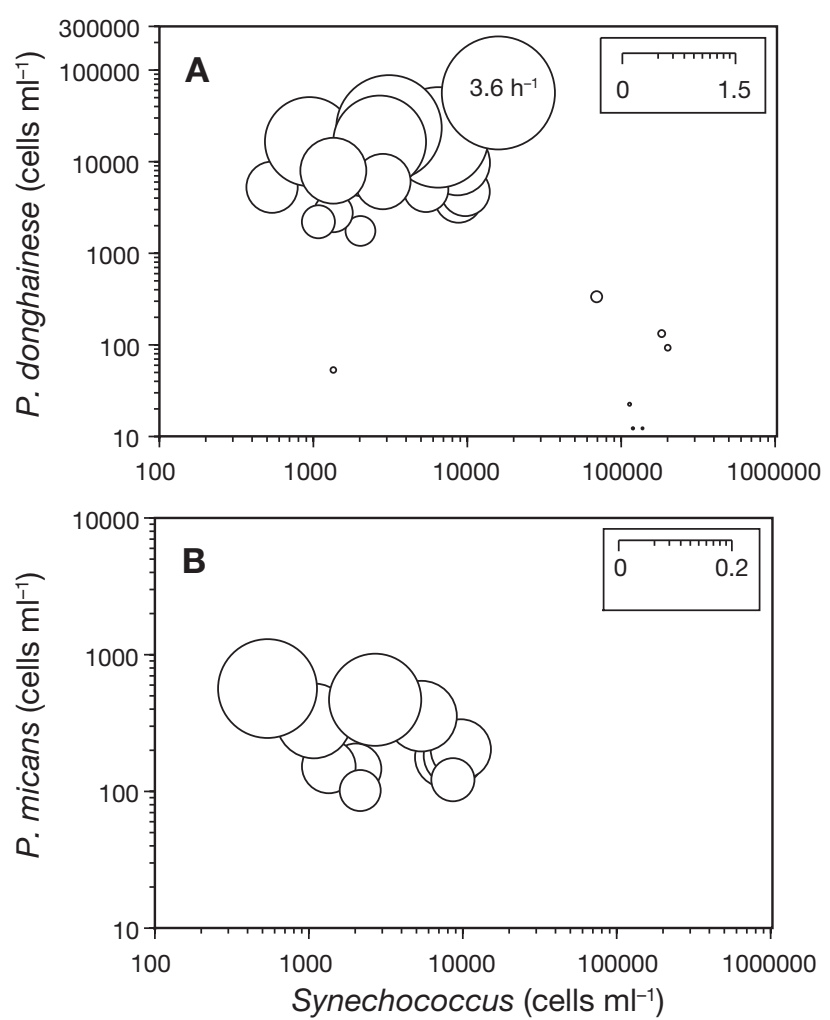

Fig. 4. Calculated grazing coefficients $(g)$ of (A) Prorocentrum donghaiense $(\mathrm{n}=24)$ and $(\mathrm{B}) P$. micans $(\mathrm{n}=11)$ in relation to the concentration of co-occurring Synechococcus (see 'Materials and methods' for calculation). The value of $g$ for $P$. donghaiense was $3.6 \mathrm{~h}^{-1}$ when the concentrations of Synechococcus and $P$. donghaiense $+P$. minimum were 16123 and 55000 cells ml${ }^{-1}$. The scale for this $g$ was reduced. Clearance rates, measured under the conditions provided in the present study, were corrected using $Q_{10}=2.8$ (Hansen et al. 1997) because in situ water temperatures and the temperature used in the laboratory for this experiment $\left(20^{\circ} \mathrm{C}\right)$ were sometimes different. The scales of the circles in the inset boxes are $g\left(\mathrm{~h}^{-1}\right)$

Karenia brevis, which had been previously thought to be exclusively autotrophic dinoflagellates, were mixotrophic species. The other dinoflagellates tested in the present study have already been classified as mixotrophic (Bockstahler \& Coats 1993, Jacobson \& Anderson 1996, Stoecker et al. 1997, Legrand et al. 1998, Jeong et al. 2004, 2005a,b). Feeding by mixotrophic dinoflagellates on Synechococcus may be an important factor in marine planktonic communities in the following ways. (1) In food webs, the pathway from one of the most abundant photosynthetic microorganisms in the world's oceans (Ferris \& Palenik 1998, Li 1998) to the mixotrophic dinoflagellates is a new discovery. So far, most studies have reported that heterotrophic nanoflagellates and ciliates are responsible for the mortality of Synechococcus due to predation. In the future we should take mixotrophic dinoflagellates into consideration as important predators on Synechococ- cus. (2) Synechococcus may be too small to be eaten by filter-feeding copepods, while many red-tide dinoflagellates are easily eaten by these grazers (Nival \& Nival 1976, Berggreen et al. 1988, Jeong 1995). Therefore, dinoflagellates might be a link between Synechococcus and some metazooplankters that are unable to ingest Synechococcus directly. (3) Some dinoflagellates such as $K$. brevis, $P$. donghaiense, and $P$. minimum formed red tides in offshore and/or oceanic waters, where the nutrient concentrations were low (Tyler \& Seliger 1978, Tester \& Steidinger 1997). Because Synechococcus are usually abundant in offshore and/or oceanic waters, it may be an important prey source for the red-tide dinoflagellates there. (4) Some studies suggested that besides iron limitation, high microzooplankton grazing pressure could be one of the reasons why the biomass of picophytoplankton (mainly Synechococcus) in oceanic waters with high nutrient concentrations remains fairly constant (e.g. Wells et al. 1994). Feeding by mixotrophic dinoflagellates may be another mechanism for limiting the excessive growth of picophytoplankton there.

\section{Ingestion rates}

Prior to this present study, there have been no data on the ingestion rate of mixotrophic dinoflagellates on Synechococcus. When prey concentrations were 1.1 to $2.3 \times 10^{6}$ cells $\mathrm{ml}^{-1}$, ingestion rates of the red-tide dinoflagellates on Synechococcus sp. varied from 1 to 64 cells dinoflagellate ${ }^{-1} \mathrm{~h}^{-1}$. Data from these studies show that the ingestion rates of 17 cultured red-tide dinoflagellates on Synechococcus sp. are positively correlated with the ESDs of the dinoflagellates (Fig. 5). This relationship suggests that the sizes of the algal predators may be an important factor affecting their ingestion rates on Synechococcus.

When the carbon content for Synechococcus sp., estimated from cell volume $\left(1 \mathrm{\mu m}^{3}\right)$ according to Strathmann (1967), is $0.2 \mathrm{pg} \mathrm{C} \mathrm{cell}^{-1}$, the maximum ingestion rate of Prorocentrum donghaiense on Synechococcus sp. (1.5 pg C dinoflagellate $\mathrm{e}^{-1} \mathrm{~h}^{-1}$ ) was slightly higher than those on a cryptophyte $\left(1.1 \mathrm{pg} C\right.$ dinoflagellate ${ }^{-1}$ $\mathrm{h}^{-1}$ ), while the maximum ingestion rate of $P$. micans on a Synechococcus sp. (7.5 pg C dinoflagellate ${ }^{-1} \mathrm{~h}^{-1}$ ) was much higher than that on a cryptophyte (1.7 pg $\mathrm{C}$ dinoflagellate $^{-1} \mathrm{~h}^{-1}$ ) (Jeong et al. 2005b). The maximum ingestion rate of $P$. micans $(\mathrm{ESD}=26.6 \mu \mathrm{m})$ feeding on a Synechococcus sp. under the conditions provided in the present study was slightly higher than that of Cochlodinium polykrikoides $(\mathrm{ESD}=25.9 \mu \mathrm{m})$ on $\mathrm{a}$ cryptophyte (6.7 pg C dinoflagellate $\mathrm{C}^{-1} \mathrm{~h}^{-1}$ ) (Jeong et al. 2004) and the same as that of Gonyaulax polygramma $(\mathrm{ESD}=32.5 \mu \mathrm{m})$ on the cryptophyte $(7.5 \mathrm{pg} \mathrm{C}$ dinofla- 


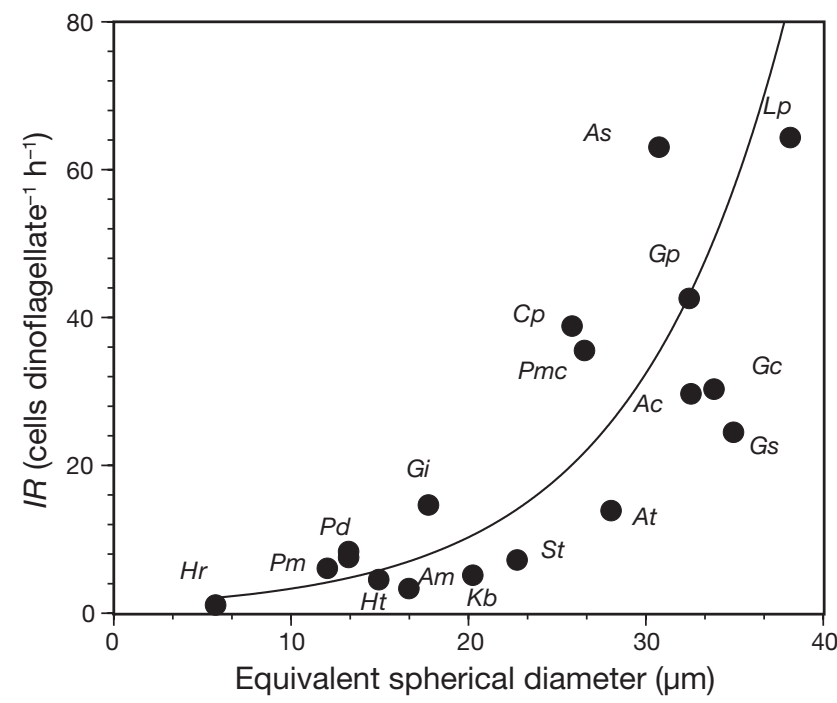

Fig. 5. Ingestion rates (IRs) of 17 red-tide dinoflagellates on Synechococcus as a function of dinoflagellate size (equivalent spherical diameter, $\mu \mathrm{m})$. The equation of the regression was IR (cells dinoflagellate $\left.{ }^{-1} \mathrm{~h}^{-1}\right)=0.991 \mathrm{e}^{(0.116 \times \mathrm{ESD})}, \mathrm{r}^{2}=0.999$ when the equivalent spherical diameters were 5.2 to $38.2 \mu \mathrm{m}$. Ac: Alexandrium catenella; At: A. tamarense; Am: A. minutum; As: Akashiwo sanguinea; Cp: Cochlodinium polykrikoides; Gp: Gonyaulax polygramma; Gs: Gonyaulax spinifera; Gc: Gymnodinium catenatum; Gi: Gymnodinium impudicum; Hr: Heterocapsa rotundata; Ht: H. triquetra; $K b$ : Karenia brevis; Lp: Lingulodinium polyedrum; Pd: $P$. donghaiense; Pmc: Prorocentrum micans; Pm: P. minimum; St: Scrippsiella trochoidea

gellate ${ }^{-1} \mathrm{~h}^{-1}$ ) (Jeong et al. 2005a). If the dinoflagellates having similar sizes have similar ingestion rates as shown above, Synechococcus may be an optimal prey for $P$. micans.

The maximum ingestion rate of Prorocentrum donghaiense on a Synechococcus sp. was higher than that of the small heterotrophic nanoflagellate Picophagus flagellatus or Pseudobodo sp. on Synechococcus sp. (Guillou et al. 2001, Christaki et al. 2002), but lower than that of the heterotrophic nanoflagellate Cafeteria

Table 3. Comparison of ingestion and clearance rates in red-tide dinoflagellates (DIN), heterotrophic nanoflagellates (HNF), and ciliates (CIL) when fed on Synechococcus. Rates are corrected to $20^{\circ} \mathrm{C}$ using $Q_{10}=2.8$ (Hansen et al. 1997). PDV: predators' volume, as $\mu^{3}{ }^{3} I_{\max }$ : maximum ingestion rate, as cells dinoflagellate ${ }^{-1} \mathrm{~h}^{-1} ; C_{\max }$ : maximum clearance rate, as $\mathrm{m} \mu l$ dinoflagellate ${ }^{-1} \mathrm{~h}^{-1}$

\begin{tabular}{lcccl} 
Predator & PDV & $I_{\max }$ & $C_{\max }$ & Source \\
\hline Prorocentrum donghaiense (DIN) & 1200 & 7.7 & 2.6 & Present study \\
Prorocentrum micans (DIN) & 9900 & 38.2 & 4.3 & Present study \\
Picophagus flagellatus (HNF) & 8 & 0.8 & 2.8 & Guillou et al. (2001) \\
Pseudobodo sp. (HNF) & 14 & 3.3 & 13.4 & Christaki et al. (2002) \\
Cafeteria roenbergensis (HNF) & 20 & 15.1 & - & Boenigk et al. (2001) \\
Bodo saltans (HNF) & 45 & 2.0 & - & Dolan \& Šimek (1998) \\
Uronema sp. (CIL) & 8300 & 31.0 & 148.2 & Christaki et al. (1999) \\
Strombidium sulcatum (CIL) & 157000 & 96.0 & 515.0 & Christaki et al. (1999) \\
\end{tabular}

roenbergensis (Boenigk et al. 2001), when corrected to $20^{\circ} \mathrm{C}$ using $Q_{10}=2.8$ (Hansen et al. 1997) (Table 3). The maximum ingestion rate of $P$. micans on Synechococcus was also comparable to that of the ciliate Uronema sp., having a volume similar to this dinoflagellate. Therefore, the red-tide dinoflagellates have ingestion rates comparable to the heterotrophic nanoflagellates and ciliates when fed on a Synechococcus sp., and thus these grazers may sometimes compete with one another for a Synechococcus if they co-occur.

\section{Grazing impact}

Grazing coefficients $(g)$ attributable to Prorocentrum donghaiense and P. micans on co-occurring Synechococcus in Masan Bay, Korea, were up to 3.6 and $0.15 \mathrm{~h}^{-1}$, respectively (i.e. up to 98 and $17 \%$ of Synechococcus populations were removed by the populations of $P$. donghaiense and $P$. micans, respectively, in $1 \mathrm{~h}$ ). Therefore, $P$. donghaiense and $P$. micans may sometimes have a considerable grazing impact on populations of co-occurring Synechococcus in Masan Bay. However, grazing coefficients attributable to P. donghaiense in offshore and/or oceanic waters away from Jeju Island, Korea, were up to $0.014 \mathrm{~h}^{-1}$ (i.e. up to $1.5 \%$ of a Synechococcus population was removed by a population of $P$. donghaiense in $1 \mathrm{~h}$ ). The removal of $23 \%$ of a Synechococcus population by a population of $P$. donghaiense per day in offshore and/or oceanic waters may not be absolutely low, but it is relatively much lower than that in Masan Bay. High abundances of Synechococcus (70 000 to 203000 cells $\mathrm{ml}^{-1}$ ) compared to the abundances of $P$. donghaiense (12 to 328 cells $\mathrm{ml}^{-1}$ ) in oceanic waters are responsible for these relatively lower grazing coefficients. The maximum concentration of $P$. donghaiense so far reported was 360000 cells ml $\mathrm{m}^{-1}$ in the offshore/oceanic waters of the East China Sea (Lu et al. 2002), but in this case $g$ could not be calculated, because data on the concentrations of co-occurring Synechococcus had not been reported. If the abundances of $P$. donghaiense were 360000 cells $\mathrm{ml}^{-1}, P$. donghaiense could almost eliminate Synechococcus in a few minutes at a Synechococcus concentration of 203000 cells $\mathrm{ml}^{-1}$. Some dinoflagellates such as $K$. brevis, $P$. donghaiense, and $P$. minimum, which sometimes form red tides in offshore and/or oceanic waters may have considerable grazing impact on populations of co-occurring Synechococcus (Tyler \& Seliger 1978, Tester 
\& Steidinger 1997). However, the grazing rates of some mixotrophic dinoflagellates are known to be affected by light and/or nutrient conditions (Hansen \& Nielsen 1997, Steocker et al. 1997, Jeong et al. 1999, Hansen et al. 2000, Jakobsen et al. 2000, Li et al. 2000, Skovgaard et al. 2000, Smalley et al. 2003). Therefore, the grazing impact of dinoflagellate predators on co-occurring Synechococcus may also be affected by light and/or nutrient conditions. Also, co-occurring phototrophic plankton cells may affect the grazing impact by dinoflagellate predators on Synechococcus, because many dinoflagellate predators have been known to feed on phototrophic plankton (Stoecker et al. 1997, Jeong et al. 1999, 2004, 2005a,b).

Acknowledgements. We thank Tae Hoon Kim, Seong Taek Kim, Jae Yoon Song, Jong Hyeok Kim, Nam Seon Kang, and Seung Hyun Lee for technical support. This paper was funded by a grant from the Korean Research Foundation (R02-2004000-10033-0) awarded to H.J.J. and an NRL grant from MOST \& KOSEF (M1-0302-00-0068) awarded to W.H.Y.

\section{LITERATURE CITED}

Agawin NSR, Duarte CM, Agusti S (1998) Growth and abundance of Synechococcus sp. in a Mediterranean Bay: seasonality and relationship with temperature. Mar Ecol Prog Ser 170:45-53

Agawin NSR, Duarte CM, Agust S, McManus L (2003) Abundance, biomass and growth rates of Synechococcus sp. in a tropical coastal ecosystem (Philippines, South China Sea). Estuar Coast Shelf Sci 56:493-502

Agawin NSR, Duarte CM, Agusti S, Vaque D (2004) Effect of $\mathrm{N}: \mathrm{P}$ ratios on response of Mediterranean picophytoplankton to experimental nutrient inputs. Aquat Microb Ecol 34: $57-67$

Andreoli C, Bresciani E, Moro I, Scarabel L, La Rocca N, Valle LD, Ghion F (1999) A survey on a persistent greenish bloom in the Comacchio Lagoons (Ferrara Italy). Bot Mar 42:467-479

Arin L, Moran XAG, Estrada M (2002) Phytoplankton size distribution and growth rates in the Alboran Sea (SW Mediterranean): short term variability related to mesoscale hydrodynamics. J Plankton Res 24:1019-1033

Berggreen B, Hansen B, Kiørboe T (1988) Food size spectra, ingestion and growth of the copepod Acartia tonsa during development: implications for determination of copepod production. Mar Biol 99:341-352

Bettarel Y, Dolan JR, Hornak K, Lemee R and 5 others (2002) Strong, weak, and missing links in a microbial community of the N.W. Mediterranean Sea. FEMS Microbiol Ecol 42: 451-462

Bockstahler KR, Coats DW (1993) Grazing of the mixotrophic dinoflagellate Gymnodinium sanguineum on the ciliate population of Chesapeake Bay. Mar Biol 116:447-487

Boenigk J, Matz C, Juergens K, Arndt H (2001) The influence of preculture conditions and food quality on the ingestion and digestion process of three species of heterotrophic nanoflagellates. Microb Ecol 42:168-176

Burkill PH, Leakey RJG, Owens NJP, Mantoura RFC (1993) Synechococcus and its importance to the microbial food web of the northwestern Indian Ocean. Deep-Sea Res II 40:773-778
Campbell L, Carpenter EJ (1986) Estimating the grazing pressure of heterotrophic nanoplankton on Synechococcus spp. using the sea water dilution and selective inhibitor techniques. Mar Ecol Prog Ser 132:121-129

Campbell L, Landry MR, Constantinou J, Nolla HA, Brown SL, Liu H, Caron DA (1998) Response of microbial community structure to environmental forcing in the Arabian Sea. Deep-Sea Res II 45:2301-2325

Caron DA, Lim EL, Miceli G, Waterbury JB, Valois FW (1991) Grazing and utilization of chroococcoid cyanobacteria and heterotrophic bacteria by protozoa in laboratory cultures and a coastal plankton community. Mar Ecol Prog Ser 76: 205-217

Chang J, Carpenter EJ (1994) Inclusion bodies in several species of Ceratium Schrank (Dinophyceae) from the Caribbean Sea examined with DNA-specific staining. J Plankton Res 16:197-202

Chang J, Chung CC, Gong G-C (1996) Influences of cyclones on chlorophyll a concentration and Synechococcus abundance in a subtropical western Pacific coastal ecosystem. Mar Ecol Prog Ser 140:199-205

Chang J, Lin KH, Chen KM, Gong GC, Chiang KP (2003) Synechococcus growth and mortality rates in the East China Sea: range of variations and correlation with environmental factors. Deep-Sea Res II 50:1265-1278

Chavez FP, Buck KR, Service SK, Newton J, Barber RT (1996) Phytoplankton variability in the central and eastern tropical Pacific. Deep-Sea Res II 43:835-870

Chiang KP, Kuo MC, Chang J, Wang RH, Gong GC (2002) Spatial and temporal variation of the Synechococcus population in the East China Sea and its contribution to phytoplankton biomass. Cont Shelf Res 22:3-13

Christaki U, Jacquet S, Dolan JR, Vaulot D, Rassoulzadegan F (1999) Growth and grazing on Prochlorococcus and Synechococcus by two marine ciliates. Limnol Oceanogr 144: $52-61$

Christaki U, Courties C, Karayanni H, Giannakourou A, Maravelias C, Kormas KA, Lebaron P (2002) Dynamic characteristics of Prochlorococcus and Synechococcus consumption by bacterivorous nanoflagellates. Microb Ecol 43:341-352

Cowlishaw RJ (2000) The impact of differential grazing by phagotrophic ciliates on phytoplankton biomass and community structure. J Phycol 36:16

Crosbie ND, Furnas MJ (2001) Abundance distribution and flow-cytometric characterization of picophytoprokaryote populations in central $\left(17^{\circ} \mathrm{S}\right)$ and southern $\left(20^{\circ} \mathrm{S}\right)$ shelf waters of the Great Barrier Reef. J Plankton Res 23: 809-828

Diaz C, Maske H (2000) Abundance of coccoid cyanobacteria hydrographic parameters and the possible underestimation of in situ chlorophyll $a$ in the northern Gulf of California and the Mexican California Current. Cienc Mar 26:441-461

DiTullio GR, Geesey ME, Jones DR, Daly KL, Campbell L, Smith WO Jr (2003) Phytoplankton assemblage structure and primary productivity along $170^{\circ} \mathrm{W}$ in the South Pacific Ocean. Mar Ecol Prog Ser 255:55-80

Dolan JR, Šimek K (1998) Ingestion and digestion of an autotrophic picoplankter Synechococcus by a heterotrophic nanoflagellate Bodo saltans. Limnol Oceanogr 43: 1740-1746

Dolan JR, Šimek K (1999) Diel periodicity in Synechococcus populations and grazing by heterotrophic nanoflagellates: analysis of food vacuole contents. Limnol Oceanogr 44: 1565-1570

Duyl F, Gast GJ, Steinhoff W, Kloff S, Veldhuis MJW, Bak 
RPM (2002) Factors influencing the short-term variation in phytoplankton composition and biomass in coral reef waters. Coral Reefs 21:293-306

Ferris MJ, Palenik B (1998) Niche adaptation in ocean cyanobacteria. Nature 396:226-228

Frost BW (1972) Effects of size and concentration of food particles on the feeding behavior of the marine planktonic copepod Calanus pacificus. Limnol Oceanogr 17:805-815

Granéli E, Anderson DM, Carlsson P, Maestrini SY (1997) Light and dark carbon uptake by Dinophysis species in comparison to other photosynthetic and heterotrophic dinoflagellates. Aquat Microb Ecol 13:177-186

Guillard RRL, Ryther JH (1962) Studies of marine planktonic diatoms. I. Cyclotella nana Hustedt and Detonula confervacea (Cleve) Grun. Can J Microbiol 8:229-239

Guillou L, Jacquet S, Chretiennot-Dinet MJ, Vaulot D (2001) Grazing impact of two small heterotrophic flagellates on Prochlorococcus and Synechococcus. Aquat Microb Ecol 26:201-207

Hansen PJ, Nielsen TG (1997) Mixotrophic feeding of Fragilidium subglobosum (Dinophyceae) on three species of Ceratium: effects of prey concentration, prey species and light intensity. Mar Ecol Prog Ser 147:187-196

Hansen PJ, Bjornsen PK, Hansen BW (1997) Zooplankton grazing and growth: scaling within the $2-2,000-\mathrm{m} \mu \mathrm{m}$ body size range. Limnol Oceanogr 42:687-704

Hansen PJ, Skovgaard A, Glud RN, Stoecker DK (2000) Physiology of the mixotrophic dinoflagellate Fragilidium subglobosum. 2. Effects of time scale and prey concentration on photosynthetic performance. Mar Ecol Prog Ser 201: 137-146

Heinbokel JF (1978) Studies on the functional role of tintinnids in the Southern California Bight. I. Grazing and growth rates in laboratory cultures. Mar Biol 47:177-189

Henley WJ, Yin Y (1998) Growth and photosynthesis of marine Synechococcus (Cyanophyceae) under iron stress. J Phycol 34:94-103

Jacobson DM, Anderson DM (1996) Widespread phagocytosis of ciliates and other protists by marine mixotrophic and heterotrophic thecate dinoflagellates. J Phycol 32:279-285

Jakobsen HH, Hansen PJ, Larsen J (2000) Growth and grazing responses of two chloroplast-retaining dinoflagellates: effect of irradiance and prey species. Mar Ecol Prog Ser 201:121-128

Jeong HJ (1995) The interactions between microzooplanktonic grazers and dinoflagellates causing red tides in the open coastal waters off southern California. PhD thesis, University of California, San Diego, CA

Jeong HJ, Shim JH, Kim JS, Park JY, Lee CW, Lee Y (1999) The feeding by the thecate mixotrophic dinoflagellate Fragilidium cf. mexicanum on red tide and toxic dinoflagellate. Mar Ecol Prog Ser 176:263-277

Jeong HJ, Yoo YD, Kim JS, Kim TH, Kim JH, Kang NS, Yih WH (2004) Mixotrophy in the phototrophic harmful alga Cochlodinium polykrikoides (Dinophycean): prey species, the effects of prey concentration and grazing impact. J Eukaryot Microb 51:563-569

Jeong HJ, Yoo YD, Seong KA, Kim JH and 5 others (2005a) Feeding by the mixotrophic dinoflagellate Gonyaulax polygramma: mechanisms, prey species, the effects of prey concentration, and grazing impact. Aquat Microb Ecol 38:249-257

Jeong HJ, Yoo YD, Park JY, Song JY, Kim ST, Lee SH, Kim KY, Yih WH (2005b) Feeding by phototrophic red-tide dinoflagellates: five species newly revealed and six species previously known to be mixotrophic. Aquat Microb Ecol 40:133-150
Jochem FJ (2003) Photo- and heterotrophic pico- and nanoplankton in the Mississippi River plume: distribution and grazing activity. J Plankton Res 25:1201-1214

Karlson B, Edler L, Graneli W, Sahlsten E, Kuylenstierna M (1996) Subsurface chlorophyll maxima in the Skagerrakprocesses and plankton community structure. J Sea Res 35:139-158

Kuosa H (1990) Protozoan grazing on pico- and nanophytoplankton in the northern Baltic Sea: direct evidence from epifluorescence microscopy. Arch Hydrobiol 119:257-265

Landry MR, Kirshtein J, Constantinou J (1996) Abundances and distributions of picoplankton populations in the Central Equatorial Pacific from $12^{\circ} \mathrm{N}$ to $12^{\circ} \mathrm{S}, 140^{\circ} \mathrm{W}$. DeepSea Res II 43:871-890

Legrand C, Graneli E, Carlsson P (1998) Induced phagotrophy in the photosynthetic dinoflagellate Heterocapsa triquetra. Aquat Microb Ecol 15:65-75

Lewitus AJ, Koepfler ET, Morris JT (1998) Seasonal variation in the regulation of phytoplankton by nitrogen and grazing in a salt-marsh estuary. Limnol Oceanogr 43:636-646

Li A, Stoecker DK, Coats DW (2000) Mixotrophy in Gyrodinium galatheanum (Dinophyceae): grazing responses to light intensity and inorganic nutrients. J Phycol 36:33-45

Li WKW (1998) Annual average abundance of heterotrophic bacteria and Synechococcus in surface ocean waters. Limnol Oceanogr 43:1746-1753

Lindell D, Post AF (1995) Ultraphytoplankton succession is triggered by deep winter mixing in the Gulf of Aqaba (Eilat) Red Sea. Limnol Oceanogr 40:1130-1141

Liu H, Suzuki K, Saino T (2002) Phytoplankton growth and microzooplankton grazing in the subarctic Pacific Ocean and the Bering Sea during summer 1999. Deep-Sea Res I 49:363-375

Lu D, Goeble J, Yuzao Q, Zou J (2002) Prorocentrum donghaiense a high biomass bloom-forming species in the East China Sea. Harmful Algae News 23:1-4

Mackey DJ, Blanchot J, Higgins HW, Neveux J (2002) Phytoplankton abundances and community structure in the Equatorial Pacific. Deep-Sea Res II 49:2561-2582

Maranon E, Behrenfeld MJ, Gonzalez N, Mourino B, Zubkov MV (2003) High variability of primary production in oligotrophic waters of the Atlantic Ocean: uncoupling from phytoplankton biomass and size structure. Mar Ecol Prog Ser 257:1-11

Monger BC, Landry MR, Brown SL (1999) Feeding selection of heterotrophic marine nanoflagellates based on the surface hydrophobicity of their picoplankton prey. Limnol Oceanogr 44:1917-1927

Morel A (1997) Consequences of a Synechococcus bloom upon the optical properties of oceanic (case 1) waters. Limnol Oceanogr 42:1746-1754

Murrell MC, Lores EM (2004) Phytoplankton and zooplankton seasonal dynamics in a subtropical estuary: importance of cyanobacteria. J Plankton Res 26:371-382

Nival P, Nival S (1976) Particle retention efficiencies of a herbivorous copepod, Acartia clausi (adult and copepodite stages): effects on grazing. Limnol Oceanogr 21:25-49

Nielsen TG, Bjoernsen PK, Boonruang P, Fryd M and 9 others (2004) Hydrography, bacteria and protist communities across the continental shelf and shelf slope of the Andaman Sea (NE Indian Ocean). Mar Ecol Prog Ser 274: 69-86

Ochs CA, Eddy LP (1998) Effects of UV-A (320 to 399 nanometers) on grazing pressure of a marine heterotrophic nanoflagellate on strains of the unicellular cyanobacteria Synechococcus spp. Appl Environ Microbiol 64: 287-293 
Partensky F, Blanchot J, Lantoine F, Neveux J, Marie D (1996) Vertical structure of picophytoplankton at different trophic sites of the tropical northeastern Atlantic Ocean. Deep-Sea Res I 43:1191-1213

Partensky F, Blanchot J, Vaulot D (1999) Differential distribution and ecology of Prochlorococcus and Synechococcus in oceanic waters: a review. Bull Inst Oceanogr Monaco 19: 457-475

Phlips EJ, Badylak S (1996) Spatial variability in phytoplankton standing crop and composition in a shallow inner-shelf lagoon Florida Bay Florida. Bull Mar Sci 58:203-216

Pitta P, Giannakourou A, Christaki U (2001) Planktonic ciliates in the oligotrophic Mediterranean Sea: longitudinal trends of standing stock distributions and analysis of food vacuole contents. Aquat Microb Ecol 24:297-311

Quevedo M, Anadon R (2001) Protist control of phytoplankton growth in the subtropical north-east Atlantic. Mar Ecol Prog Ser 221:29-38

Rivkin RB, Putland JN, Anderson MR, Deibel D (1999) Microzooplankton bacterivory and herbivory in the NE subarctic Pacific. Deep-Sea Res II 46:2579-2618

Siegler R, Sternson LA, Stobaugh JF (1989) Suitability of DTAF as a fluorescent labelling reagent for direct analysis of primary and secondary amines-spectral and chemical reactivity considerations. J Pharm Biomed Anal 7:45-55

Sherr BF, Sherr EB, Fallon RD (1987) Use of monodispersed, fluorescently labeled bacteria to estimate in situ protozoan bacterivory. Appl Environ Microbiol 53:958-965

Sherry ND, Wood AM (2001) Phycoerythrin-containing picocyanobacteria in the Arabian Sea in February 1995: diel patterns spatial variability and growth rates. Deep-Sea Res II 48:6-7

Šimek K (1997) Processing of ingested matter in Strombidium sulcatum a marine ciliate (Oligotrichida). Limnol Oceanogr 42:393-397

Skovgaard A, Hansen PJ, Stoecker DK (2000) Physiology of the mixotrophic dinoflagellate Fragilidium subglobosum. 1. Effects of phagotrophy and irradiance on photosynthesis and carbon content. Mar Ecol Prog Ser 201:129-136

Smalley GW, Coats DW, Stoecker DK (2003) Feeding in the mixotrophic dinoflagellate Ceratium furca is influenced by intracellular nutrient concentrations. Mar Ecol Prog Ser 262:137-151

Stal LJ, Albertano P, Bergman B, Von Brockel K, Gallon JR, Hayes K, Sivonen K, Walsby AE (2003) BASIC: Baltic Sea cyanobacteria. An investigation of the structure and dynamics of water blooms of cyanobacteria in the Baltic Sea-responses to a changing environment. Cont Shelf Res 23:1695-1714

Strom SL (1991) Growth and grazing rates of the herbivorous dinoflagellate Gymnodinium sp. from the open subarctic Pacific Ocean. Mar Ecol Prog Ser 178:103-113

Stoecker DK (1999) Mixotrophy among dinoflagellates. J Eukaryot Microbiol 46:397-401

Stoecker DK, Li A, Coats DW, Gustafson DE, Nannen MK (1997) Mixotrophy in the dinoflagellate Prorocentrum

Editorial responsibility: David A. Caron,

Los Angeles, California, USA minimum. Mar Ecol Prog Ser 152:1-12

Strathmann RR (1967) Estimating the organic carbon content of phytoplankton from cell volume or plasma volume. Limnol Oceanogr 12:411-418

Tarran GA, Burkill PH, Edwards ES, Woodward EMS (1999) Phytoplankton community structure in the Arabian Sea during and after the SW monsoon 1994. Deep-Sea Res II 46:655-676

Tarran GA, Zubkov MV, Sleigh MA, Burkill PH, Yallop M (2001) Microbial community structure and standing stocks in the NE Atlantic in June and July of 1996. Deep-Sea Res II 48:963-985

Taslakian MJ, Hardy JT (1976) Sewage nutrient enrichment and phytoplankton ecology along the central coast of Lebanon. Mar Biol 38:315-325

Tester PA, Steidinger KA (1997) Gymnodinium breve red tide blooms: initiation, transport, and consequences of surface circulation. Limnol Oceanogr 42:1039-1051

Timmermans KR, Gledhill M, Nolting RF, Veldhuis MJW, de Baar HJW, van den Berg CMG (1998) Ecophysiological responses of marine phytoplankton in iron enrichment experiments in the northern North Sea and northeast Atlantic Ocean. Mar Chem 61:229-242

Tyler MA, Seliger HH (1978) Annual subsurface transport of a red tide dinoflagellate to its bloom area: water circulation patterns and organism distributions in the Chesapeake Bay. Limnol Oceanogr 23:227-246

Uysal Z (2000) Pigment size and distribution of Synechococcus spp. in the Black Sea. J Mar Syst 24:313-326

Vezina S, Vincent WF (1997) Arctic cyanobacteria and limnological properties of their environment: Bylot Island, Northwest Territories, Canada $\left(73^{\circ} \mathrm{N}, 80^{\circ} \mathrm{W}\right)$. Polar Biol 17:523-534

Walker TD, Marchant HJ (1989) The seasonal occurrence of chroococcoid cyanobacteria at an Antarctic coastal site. Polar Biol 9:193-196

Wawrik B, Paul JH (2004) Phytoplankton community structure and productivity along the axis of the Mississippi River plume in oligotrophic Gulf of Mexico waters. Aquat Microb Ecol 35:185-196

Wells ML, Price NM, Bruland KW (1994) Iron limitation and the cyanobacterium Synechococcus in equatorial Pacific waters. Limnol Oceanogr 39:1481-1486

Worden AZ, Binder BJ (2003) Application of dilution experiments for measuring growth and mortality rates among Prochlorococcus and Synechococcus populations in oligotrophic environments. Aquat Microb Ecol 30:159-174

Yahel G, Post AF, Fabricius K, Marie D, Vaulot D, Genin A (1998) Phytoplankton distribution and grazing near coral reefs. Limnol Oceanogr 43:551-563

Yin Y, Henley WJ (1999) Iron-limited semicontinuous culture studies of marine Synechococcus. Bull Inst Oceanogr Monaco Suppl:365-368

Zubkov MV, Sleigh MA, Tarran GA, Burkill PH, Leakey RJG (1998) Picoplanktonic community structure on an Atlantic transect from $50^{\circ} \mathrm{N}$ to $50^{\circ} \mathrm{S}$. Deep-Sea Res I 45:1339-1355

Submitted: June 5, 2005; Accepted: August 27, 2005

Proofs received from author(s): November 10, 2005 